\title{
A STUDY ON EMPLOYEE ENGAGEMENT
}

\author{
*Sonal Lobo $\quad * *$ Ashwini.R
}

\section{ABSTRACT}

In today's rapidly changing business scenario, one of the toughest challenges that business leaders face is sustaining high level of performance over the long term and obtaining superior business results. Employee Engagement is a route to business success. One of the biggest problems facing businesses is how to motivate and keep workers engaged. An engaged workplace encourages commitment, energy and productivity from all those involved to help improve business performance. Employee engagement goes hand in hand with higher job satisfaction, lower employee turnover and better profitability. This paper makes an attempt to study in depth the concept and various dimensions of employee engagement.

Keywords: Employee engagement, Leadership, Performance, Satisfaction

\section{INTRODUCTION}

Engagement at work was conceptualized by Kahn, (1990) as the 'harnessing of Organizational members to their work roles. In engagement, people employ and Express themselves physically, cognitively, and emotionally during role performances.

Employee engagement is thus the level of commitment and involvement an employee has towards the organization and its values. An engaged employee is aware of business context, and works with colleagues to improve performance within the job for the benefit of the organization. The organization must work to develop and nurture engagement, which requires a two-way relationship between employer and employee. Thus Employee engagement is a barometer that determines the association of a person with the organization. Employee engagement, also called worker engagement, is a business management concept. An "engaged employee" is one who is fully involved in, and enthusiastic about their work, and thus will act in a way that furthers their organization's interests. According to Scarlett Surveys, "Employee Engagement is a measurable degree of an employee's positive or negative emotional attachment to their job, colleagues and organization that profoundly influences their willingness to learn and perform it at work". Thus engagement is distinctively different from employee satisfaction, motivation and organizational culture. A modernized version of job satisfaction, Schmidt et al.'s influential definition of engagement was "an employee's involvement with, commitment to, and satisfaction with work". Employee engagement

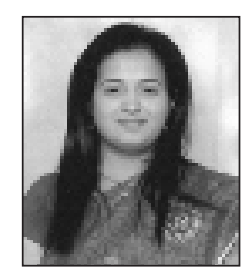

\section{*Prof. Sonal Lobo}

Lecturer

PG Department of Commerce

BMS College for Women

Bangalore

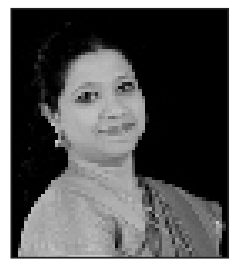

*Prof. Ashwini. R

Lecturer

PG Department of Commerce

BMS College for Women

Bangalore 
is a part of employee retention. The opposite of employee engagement is a zombie employee. A zombie employee is a disengaged employee that will stumble around the office with lower morale and cost the company money.

The idea of employee engagement is relatively new to researchers. While the theories of this construct may be blurred, many companies are beginning to see the clear picture - an engaged employee is a valuable, productive asset that can help the organization achieve its goals.

\section{REVIEW OF LITERATURE}

Kahn (1990) was the first to suggest that employee engagement would positively impact on organisational level outcomes. The reasoning behind his contention was that because employees want to work for reasons other than "they get paid to do it", they will work to pursue success for their organisation.

De Waal (2007) identified that leaders of high performance organisations are "committed to the organisation for the long haul by balancing common purpose with self-interest, and teaching Organisational members to put the organisation first."

Bhatla (2011) focused on the need for engaged employees and how their presence can improve the progress and work efficiency of the organization as a whole. Also focused on the challenges faced by the HR managers to improve employee engagement for an organization's survival.

Bijaya Kumar Sundaray (2011) focused on various factors which lead to employee engagement and what should company do to make the employees engaged. Proper attention on engagement strategies will increase the organizational effectiveness in terms of higher productivity, profits, quality, customer satisfaction, employee retention and increased adaptability.

Shashi (2011) reinforced the importance of employee communication on the success of a business. She revealed that an organization should realize the importance of employees, more than any other variable, as the most powerful contributor to an organization's competitive position

\section{OBJECTIVES OF THE STUDY}

- To understand the concept of employee engagement.

- To study in detail about the types of employee engagement

- To understand the drivers of employee engagement

- To analyze the various employee engagement activities

- To study the employee engagement strategies followed by Indian companies

\section{DEFINING EMPLOYEE ENGAGEMENT:}

According to Sanchez (2007), employee engagement is defined as "an outcome of how employees perceive their work, leadership of their organizations, the recognition and rewards they receive, and the communication ethos of the organization".

Cook (2008) defined Employee engagement as the term that is "personified by the passion and energy employee have to give of their best to the organization to serve the customer. It is all about the willingness and ability of the employees to give sustained discretionary effort to help their organization succeed". 
Porter (1974) points out that commitment involves the willingness of employees to exert higher efforts on behalf of the organization, a strong desire to stay in the organization, and accept major goals and values of the organization.

Saks (2006) argue that organizational commitment refers to a person's attitude and attachment towards their organization, whilst engagement is not merely an attitude; it is the degree to which an individual is attentive to their work and absorbed in the performance of their role.

\section{TYPES OF EMPLOYEE ENGAGEMENT}

\section{a. Engaged \\ b. Disengaged \\ a. Engaged}

Engaged employees are enthusiastic, passionate and completely absorbed in their work. They always act in ways that are in the best interest of their organization. They are driven and will always ensure that they know what their role in the organization is. These individuals are known to have high levels of performance. They want to use their skills, abilities and competencies every day at work. Engaged employees are committed to their organization, tend to stay with the organization longer and are more committed to quality and growth. These employees are very proud of their organization and will tell everybody about their organization.

Employees are engaged when:

- $\quad$ They have a strong relationship with their manager

- There is clear communication between them and their manager
- $\quad$ They have clear goals set for them; they thus know where they are going

- They have strong interpersonal relationships with colleagues

- They encourage and motivate others to take risks and strive for excellence.

\section{b. Disengaged}

Employees who are not engaged will put in the necessary time to finish a task, but will have no energy or passion for their work. They have no positive or negative feelings about their organization and go through the motions daily without committing themselves. These individuals are task orientated rather than goal orientated. They expect to be told what to do, rather than take initiative and do something of their own accord. These employees tend to feel that their efforts are not appreciated and that their full potential is not being tapped. Disengaged will most likely cost an organization a lot of money.

\section{Actively disengaged}

These individuals are opposed to everything. They are not just unhappy at work, but they are actively living out their unhappiness at work. These individuals will not miss a chance to spread negativity. Actively disengaged employees are not interested in the goals and mission of the company; they rather openly express feelings of mistrust and hatred towards it. Employees that are highly disengaged will hold back physically, cognitively and emotionally. When they work they behave in a robotic, passive and detached way. These types of employees can hurt the image and functioning of the organization. 
Following could be possible causes of actively disengaged employees:

- Poor management.

- Lack of career growth and advancement opportunities.

- Poor communication.

- Lack of recognition.

- Employees' salaries are not marketrelated.

- $\quad$ Lack of training.

- Constant work overload.

- $\quad$ Lack of teamwork.

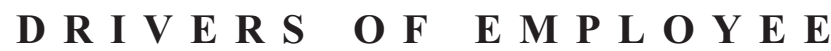
ENGAGEMENT

The Towers Perrin Talent Report (2003) identified the top ten work elements that would result in employee engagement.

These elements are:

(a) senior management's interest in employees' well-being :- Employees want to know what management thinks and what they believe. They also want the opportunity to give their input; this will give them responsibility and accountability. A very damaging fact is that sometimes there is a huge gap between what management says and does. This can destroy trust and engagement very quickly.

(b) Challenging work:-Some jobs are repetitive and mundane by nature. There are, however, ways how employers can promote a stimulating and challenging environment. These include encouraging people to take initiative, being open and accepting change, coaching and developing individual's skills, and holding people accountable for their performance.

(c) Decision-making authority:- Employees will accept increased risk much easier if they think that they have control over decisions; have the relevant information and tools to make a sound decision.

(d) Evidence that the company is focused on customers.

(e) Career advancement opportunities

(f) The company's reputation as a good employer

(g) A collaborative work environment where people work well in teams

(h) Resources to get the job done

(i) Input on decision-making and

(j) A clear vision from senior management about future success:-It is thus clear that individuals who experience a strong sense of purpose at the work-place, who believe that they have all the necessary competencies to effectively do their work, who believe that they have the ability to influence the system they are in and who have self-endorsed goals are more engaged in their work.

STRATEGIES ORGANIZATIONS CAN USE TO HELP B U ILD THEIR CONSTITUENCY OF ENGAGED EMPLOYEES:

1. Use the right employee engagement survey. When a company asks its employees for their opinions, those 
employees expect action to follow. But businesses often make the mistake of using employee surveys to collect data that are irrelevant or impossible to act on. Any survey data must be specific, relevant, and actionable for any team at any organizational level. Data should also be proven to influence key performance metrics.

2. Focus on engagement at the local and organizational levels. Real change occurs at the local workgroup level, but it happens only when company leaders set the tone from the top. Companies realize the most benefit from engagement initiatives when leaders weave employee engagement into performance expectations for managers and enable them to execute on those expectations. Managers and employees must feel empowered to make a significant difference in their immediate environment. Leaders and managers should work with employees to identify barriers to engagement and opportunities to effect positive change. Employees are familiar with the company's processes, systems, products, and customers. They are also experts on themselves and their teams. So it makes sense that they will have the best ideas to maximize these elements and deliver improved performance, business innovation, and better workplace experiences.

3. Select the right managers. The best managers understand that their success and that of the organization relies on employees' achievements. But not everyone can be a great manager. Great managers care about their people's success. They seek to understand each person's strengths and provide employees with every opportunity to use their strengths in their role. Great managers empower their employees, recognize and value their contributions, and actively seek their ideas and opinions. It takes talent to be a great manager, and selecting people who have this talent is important. Whether hiring from outside or promoting from within, businesses that scientifically select managers for the unique talents it takes to effectively manage people greatly increase the odds of engaging their employees. Companies should treat the manager role as unique, with distinct functional demands that require a specific talent set.

4. Coach managers and hold them accountable for their employees' engagement. Gallup's research has found that managers are primarily responsible for their employees' engagement levels. Companies should coach managers to take an active role in building engagement plans with their employees, hold managers accountable, track their progress, and ensure that they continuously focus on emotionally engaging their employees. The most successful managers view the Q12 as the elements for great managing, not just questions for measuring. By doing so, they gain a powerful framework to guide the creation of a strong, engaged workplace.

5. Define engagement goals in realistic, everyday terms. To bring engagement to life, leaders must make engagement goals meaningful to employees' day-to-day experiences. Describing what success 
looks like using powerful descriptions and emotive language helps give meaning to goals and builds commitment within a team. Make sure that managers discuss employee engagement at weekly meetings, in action-planning sessions, and in one-onone meetings with employees to weave engagement into daily interactions and activities and to make it part of the workplace's DNA.

\section{The 'Ten C's of Engagement'}

Steps that the management can take to enhance the level of engagement of the employees. These may be enumerated as follows:

1. Connect: the extent to which management conveys that it cares for and values the employees.

2. Career: the extent to which the management provides to the workers work that is challenging and meaningful' and fostering one's career growth.

3. Clarity: the extent to which the goals, rules and the organizational operations are transparent and understood by the employee.

4. Convey: the extent to which the management communicates goals and provides feedback.

5. Congratulate: the extent to which good performance brings praise and recognition.

6. Contribute: the extent o which one's contribution to the 'success and future' of the company is understood.

7. Control: the extent to which the management allows the worker to participate in decision making and drive initiatives.

8. Collaborate: the extent to which the organization upholds team work over pursuance of self-interests.

9. Credibility: the extent to which the management demonstrates transparency and high ethical standards.

10. Confidence: the extent to which the organization demonstrates high ethical and performance standards, creating a sense of positive identification among the employees.

\section{E M P L O Y M E N T E N G A G EM E N T ACTIVITIES}

- Have teams create their own set of values

Designing your own game rules makes playing a lot more fun. Having teams create a team culture, based on 2-3 commonly agreed values or ground rules can help nurture and speed up that process.

\section{- Encourage personal projects}

Give employees a 1-2 $\mathrm{h} /$ day window to pursue their own projects. Having people from different departments connecting and bouncing ideas can help get a new perspective.

- Assign a buddy/mentor for every newcomer

An important part of the on boarding process is having someone answer some really important questions. Questions that someone would be 
hesitant to simply ask a manager. Building a trustworthy relationship with someone with more experience in that company can help guide the newcomer. This way he or she can better adapt and grow part of the team.

- Have team photos

Have photos of your team on a wall, or frame them around the office. Group photos, funny photos, events photos or random photos snapped when people weren't watching. It's a cultural element that can encourage and foster work relationships and employee engagement.

- Encourage volunteering

If you find yourself doubting the classical money-to-charity approach, you should try the new volunteer-fora-cause angle. Give your employees a couple of days a month to volunteer for a cause they support.

- $\quad$ Raise salaries

- Recognize and encourage innovation

- Celebrate achievements

Big or small, they are the solid proof that the work people are putting in has meaning. No one can go through tasks and assignments for months, or even years without burning out. Refill their energy tanks with some recognition and celebrate their hard work.

- Celebrate people

Birthdays, promotions, retirements, newcomers welcoming, there are plenty of important moments where people can be put at the front of the company.

- Give and receive feedback

- Try some unusual employee engagement ideas

It's the small things that can sometime make a difference. Like having colored mugs at work or an awesome air freshener.

- Show respect

This should be the cornerstone for every office interaction. Especially when it comes to people in different hierarchies.

- Encourage learning

Challenge and support employees in learning and developing their skills. Not only will you have a motivated and well-prepared workforce but you'll see an increase in employee happiness and employee engagement.

- Build long-term engagement

Don't settle for a quick fix. Develop a long-term employee engagement strategy with clear objectives and action steps for more than a year, then re-evaluate and build on it.

Strategies practiced by Indian companies to encourage employee engagement

1. At Tata Consultancy Services (TCS), senior executives guide team members coming up with innovative solutions to 
work related issues / problems. This has resulted in development of a number of useful products that have resulted in successful business endeavors. TCS, which has diverse teams working in different geographic locations in different cultures, created the 'Ultimax' platform an online forum, where employees across levels and geographies can come together.

2. At Bharti Airtel Ltd, the new joinies \& the best performers for the month are rewarded with a special dinner / lunch with their Chief Operations Officer.

3. Aditya Birla Group regularly monitors employee engagement at all levels across the group through the biennial organization health study (OHS), which is led by the chairman. It gives employees a unique opportunity to anonymously and frankly express their opinions on a range of issues. The Aditya Birla Awards for Outstanding Achievement — has also been a key engagement factor. During the awards, a number of groupwise competitions are conducted. Over the years, competitions like Vision 2015, Oh! Not So Smart, Aditya Birla Group value leaders' poll, etc, have been conducted. These competitions are open to all employees of the group. "Aditya Birla Group has a single portal which provides various job opportunities across levels, businesses and geographical locations of the Group. Aditya Birla Group also has opened up various learning opportunities.

4. Indian Hotels, which operates the Taj chain of hotels, has been able to create a culture where the performance of employees is measured on customer orientation efforts and the guidance given by senior leaders.

5. A prime example of employee engagement in Tata Motors is Tata club at Jamshedpur, which serves as a gathering point for employees and their families as they come together, network and have fun. The Community Development Centres (CDCs) have also been established across India to merge family values into Tata Motors organizational culture. To promote the value of education and to highlight the achievements of employee's children, merit awards are given in academics, sports \& extracurricular activities. The artistic talent of the employees is nurtured through Kalasagar and Kalasangam - Tata Motors Cultural group. They arrange various cultural events on music, drama, dance and other activities to promote the creativity among the employees and their families.

6. Through the Employee Involvement Program, Microsoft aims to offer employees with an additional opportunity for personal and professional development, to apply and develop their skill sets through cross group collaboration, teamwork with colleagues and partners in the community, to expand personal horizons outside the Microsoft environment. Microsoft employees meet students in schools and colleges and answer questions on various aspects of their areas of expertise, mostly centered on career paths.

7. Vodafone has implemented a new model of 'customer centricity' to drive improved customer and employee satisfaction. The 
Vodafone Way is modeled on three key tenets: Speed, Simplicity \& Trust; with line managers being held accountable for team engagement with performance measures and providing them with tools and plans to drive performance by giving employees clear goals and a customer / client focus - and thereby achieving increased levels of productivity and innovation even in the downturn.

8. ITC harnesses the creative potential of all its employees by promoting a culture of partnerships to unleash relevant synergies between different groups of employees. All major changes in operations involving work processes, manning norms and other productivity linked issues are carried out after discussions with the employees and the recognized unions at each location. Implementation Business plans is shared with employees at all units through a series of formal communication meetings, and through the intranet portals.

9. In Godrej, the Company's motto is 'take yourself lightly and take your job and your responsibilities seriously'. They believe real fun at work implies that 'Work itself is fun'. In Godrej and Boyce, there are various initiatives that have been taken up by practically all the divisions and Corporate HR. Each Divisional Personnel Head organizes some fun initiatives for the division like Birthday celebrations, Annual get together, Department picnics, Attendance / Retirement functions, Festive dress codes, Dusserah /Diwali celebrations, online quizzes, Saturday casual dressing, Learning and Sharing day, Team Lunches/Movies, Sense of Humor (try to laugh at ourselves rather than others), Lights Off Day, Wall of fame to announce Employee of the Quarter/Month. Some divisions also have clip boards for pasting jokes, cartoons and job related updates.

10. Tata AIG General Insurance Co. Ltd commemorate individual and team achievements by organizing a fun filled evening for the employees. Employee Town Hall is an event where the head of the organization addresses and interacts with all employees giving them an insight about the company's progress and unfolding the way forward. Interdepartmental cricket \& football matches organized every year for sports enthusiasts helps foster a spirit of teamwork. World of Work (WOW) is another event when employees' children are invited to come and spend time at their parents' workplace.

\section{FOREIGN COMPANIES}

\section{ABC Supply}

Ken Hendricks, the late CEO of the largest roofing distribution company in the U.S., believed that "by putting your people first, your people will put the customer first." With 350 locations spread across 45 states, fostering and maintaining an engaged workforce was about creating "a people business built on relationships."

In all the relationship-building activities that Hendricks took on to bolster employee engagement, the key was to treat employees as equals, as peers and as friends. From taking an hour out of every day to talk directly to managers, to inviting hundreds of his employees 
to weekly parties at his summer home, Hendricks created a culture where people felt supported, appreciated, listened to and respected.

He even had yearbooks printed for ABC Supply employees in all 350 locations, complete with photos, employee lists, and each office's goals for the upcoming year.

Why it works: ABC Supply has continued to thrive, living by its mission "to increase customer engagement through increased employee engagement." The little details have made all the difference. The yearbooks, as well as management's commitment to strengthening inter/outer-office relationships, have proved to be powerful employee engagement activities that keep employees committed to the organization and to each other.

\section{Zappos:}

Zappos online shoe store regularly shows up on best places to work lists. The secret to its hyper engaged workforce. A commitment to company culture. Receiving over 55,000 employment applications a year, Zappos is scrupulous about hiring the right people and more importantly, keeping them. Candidates who pass the lengthy interview process that includes numerous phone and in-person interviews are asked to attend lunch and happy hour events to see if they're a good fit with the Zappos "family" and culture.

Why it works: Engagement and culture are synonymous at Zappos. The company is clear about what their culture is and what they need to do to maintain it. They've defined their core company values and focus on retaining the people who share and uphold those values. It may take long for Zappos to hire a new employee, but they're quick to let go people who don't fit the profile.

\section{Reebok}

Reebok was looking to reinforce its new mission "to get consumers moving." They figured the best way to do that was to first get their employees in motion. In an effort to align their people with their vision, the athletic apparel brand converted one of their warehouses into a Cross Fit workout center, exclusively for Reebok employees.

Why it works: This initiative helped build engagement on many levels. Reebok didn't just sell a lifestyle, it lived it. To deliver the full customer experience, they promoted a culture of health and wellness within their organization, making employees stakeholders in the company's vision and mission.

\section{CONSEQUENCES OF EMPLOYEE ENGAGEMENT}

Engaged employees will stay with the company, be an advocate of the company and its products and services, and contribute to bottom line business success.

They will normally perform better and are more motivated.

$>$ There is a significant link between employee engagement and profitability.

$>\quad$ They form an emotional connection with the company. This impacts their attitude towards the company's clients, and thereby improves customer satisfaction and service levels

It builds passion, commitment and alignment with the organization's strategies and goals 
$>$ Increases employees' trust in the organization

$>$ Creates a sense of loyalty in a competitive environment

$>$ Provides a high-energy working environment

$>$ Boosts business growth

$>$ Makes the employees effective brand ambassadors for the company

\section{CONCLUSION}

Employee Engagement is the buzz word term for employee communication. It is a positive attitude held by the employees towards the organization and its values. It is rapidly gaining popularity, use and importance in the workplace and impacts organizations in many ways.

Employee engagement emphasizes the importance of employee communication on the success of a business. An organization should thus recognize employees, more than any other variable, as powerful contributors to a company's competitive position. Therefore employee engagement should be a continuous process of learning, improvement, measurement and action.

We would hence conclude that raising and maintaining employee engagement lies in the hands of an organization and requires a perfect blend of time, effort, commitment and investment to craft a successful endeavor.

\section{REFERENCES :}

- $\quad$ Bhatla, N. (2011). To study the Employee Engagement practices and its effect on employee Performance with special reference to ICICI and HDFC Bank in Lucknow. IJSER, 2(8).

Beardwell, J. and Claydon, T. (2007). Human Resource Management, A Contemporary Approach. 5th ed. Harlow, Prentice Hall.

- Buchanan, D. \& Huczynski, A. (2004). Organizational Behaviour. An introductory text, 5th ed. Harlow, FT/Prentice Hall.

Crabtree, S. (2005). Engagement keeps the doctor away; A happy employee is a healthy employee, according to a GMJ survey. Gallup Management Journal, 13th January. Available at: www. Gmj.gallup.com Accessed on 19 December, 2012.

Cooper, R. (1997). Applying Emotional Intelligence in the workplace. Training and Development, 51(12), 31-38.

Deci, E.L. \& Ryan, R.M. (1987). The support of autonomy and the control of behaviour. Journal of Personality and Social Psychology, 53, 1024-1037. Development Dimensions International, Inc., available www.ddiworld.com (accessed on October 30, 2011)

Robertson-Smith, G. Markwick, C. (2009). Employee Engagement A review of current thinking, Institute for Employment Studies, University of Sussex Campus Brighton, UK

- Kahn, W. A. (1990). Psychological conditions of personal engagement and disengagement at work. Academy of Management Journal, 33 (4), 692-724. 
- $\quad$ Kular, S., Gatenby, M., Rees, C., Soane, E. \& Truss,K. (2008). Employee Engagement: A Literature Review. Kingston Business School, Kingston University Working Paper Series No 19, October 2008.

- Kumar, J.A. (2012). Employee Engagement, Saaransh, RKG Journal of Management, 3(2).

- Lockwood, N. R. (2007). Leveraging Employee Engagements for Competitive Advantage: HRs Strategic Role. HR Magazine, 52(3), 1-11.

- $\quad$ Lucas, R., Lupton, B. and Mathieson, H. (2006) Human Resource Management in an International Context. London, CIPD.

- Archie Thomas, CMA, and Ann MacDi anmid - Encouraging Employee Engagement - CMA Management, Jun/Jul 2004.

- Ashok Mukherjee - Engagement for the mind body, and soul - Human Capital, Aug. 2005.
Christoffer Ellehuus,Piers Hudson-Driving Performance and Retention Through Employee Engagement -Corporate leadership Council 2004,Employee Enagegement Survey.

- $\quad$ Michael Treacy - Employee Engagement higher at DDG company - Hewitt Research Brief. 2005.

- Douglas R. May, Richard L Gilson - The Psychological conditions of meaningfulness safety and availability and the engagement of the human spirit at work - Journal of Occupational and Organisational Psychology (2004) 7, 1137.

\section{WEBSITES}

www.investopedia.com www.engageforsucess.com www.forbes.com www.economictimes.com www.customsight.com 